\title{
THE UTILITY OF OIL SHOWS IN THE HYDROCARBON EXPLORATION OF WESTERN GREECE
}

\author{
Rigakis N. ${ }^{1}$, Nikolaou K. ${ }^{1}$, Marnelis F. ${ }^{1}$, and Pakos Th. ${ }^{1}$ \\ ${ }^{1}$ Hellenic Petroleum, Exploitation and Production of Hydrocarbons, 199, Kifissias ave., Maroussi \\ 15124,nrigakis@hellenic-petroleum.gr,knikolaou@hellenic-petroleum.gr,fmarnelis@hellenic- \\ petroleum.gr,tpakos@hellenic-petroleum.gr
}

\begin{abstract}
A great number of oil shows are known in Western Greece, mainly in the Ionian zone, but also in the Preapulian and Gavrovo zones. Most of the wells drilled in the area have also identified oil shows. The systematic study of these oil shows provides a useful tool for the hydrocarbon exploration of this area. First of all the presence of oil shows indicates that oil generation and migration have certainly taken place. Furthermore by their study the petroleum systems of western Greece can be confirmed. Oil shows were analyzed using chemical methods. Because most surface oil shows are biodegraded, the study was mainly based on carbon isotopes measurements and on characteristic biomarker ratios. The oil shows can be classified into five main groups, based on their different compositions, while two of them are separated in two subgroups. This differentiation proves the presence of different source rock horizons, which have generated these oils.
\end{abstract}

Key words: Biomarkers, oil group, oil correlation, oil maturity.

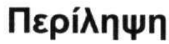

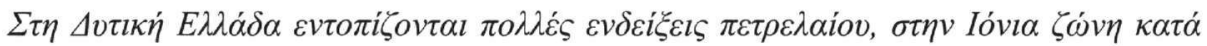

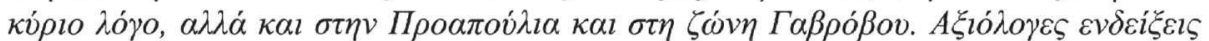

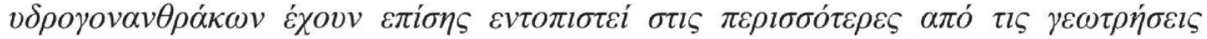

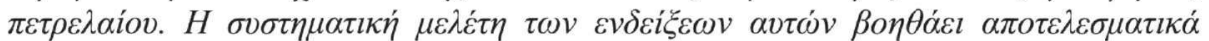

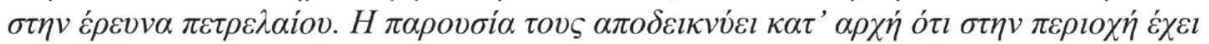

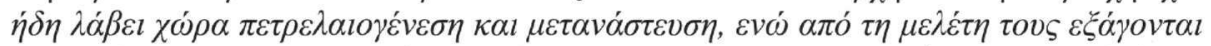

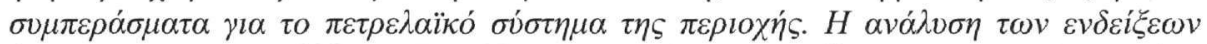

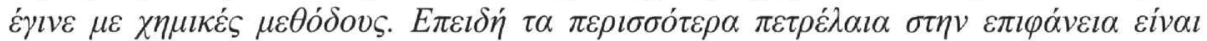

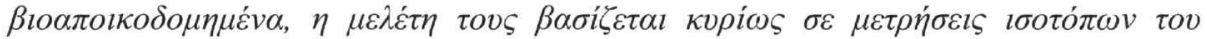

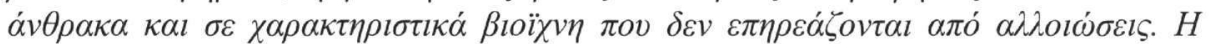

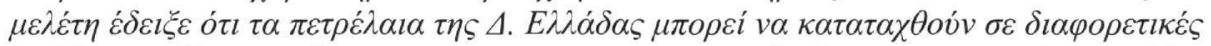

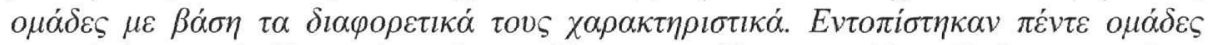

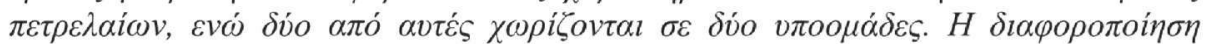

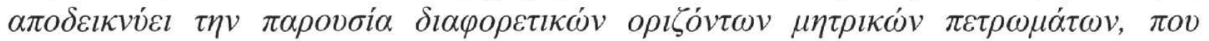

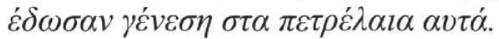

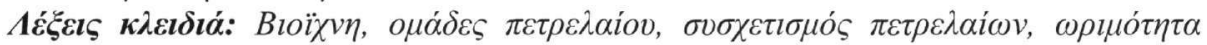
$\pi \varepsilon \tau \rho \varepsilon \lambda \alpha i \omega v$. 


\section{General settings}

Indications of liquid oil or solid tar etc can be observed at the Earth's surface in many cases and are commonly termed "oil shows". These oil shows are often the first indication of the possible presence of an oil reservoir in the area, which has leaked oil to the surface. These oil shows are the first indication that in the area oil generation and migration have already taken place and consequently the first indication for further oil exploration activities (Hunt 1979). On the other hand, the absence of shows isn't a negative factor for an area; the presence of oil shows is dependent on the geological history of the area, and the continuity of the migration paths up to the surface (Horvitz 1985). In summary oil shows can be very useful in oil exploration, while the absence of them does not discount the further exploration (Tissot and Welte 1984).

Oil shows can be separated into (1) the direct or active shows, where there is a continuous supply of hydrocarbons to the surface, and (2) in the indirect or dead shows. In this second case, oil is weathered, decomposed, oxidized and biodegraded; if alteration is extensive, it may finally turned to tar, filling faults or porous rocks, forming the so-called "tar sands". The connection with the source of supply is depended on the migration routes. Oil shows can be a result of primary migration, directly from the source rock, or can be due to secondary migration, with leakage of an oil reservoir to the surface. In both cases oil migration can be facilitated by water circulation, which can bring the oil up to the surface.

Further to the surface oil shows, in many cases oil shows can be observed in oil wells. These shows can indicate the presence of an oil field, but in most cases they are not associated with an oil field. They can be the residue of a migration path, or can be small concentrations without any economic value (Hunt 1979, Horvitz 1985).

\section{Analytical methods}

26 oil samples were analysed using chemical methods. Samples were extracted by Soxhlet (Claypool et al., 1978) and separated by column chromatography into saturated and aromatic hydrocarbon (HC) fractions, resins and asphaltenes, by column chromatography (Palacas et al. 1972). By gas chromatography (GC) of the saturated HCs', pristane and phytane (isoprenoid biomarkers) were detected and the carbon preference index (CPI) of the $n$-alkanes was measured. Isoprenoids and CPI were used as depositional indicators (Claypool et al. 1978, Tissot and Welte 1984). Carbon isotopes and biomarkers determined by GC-mass spectrometry (GC-MS) were found to be the most useful tool for correlation purposes, and as depositional environment indicators (Peters and Moldowan 1993).

For oil classification it is accepted that carbon isotope variation should not exceed the 3\%o (Sofer 1984). Biomarkers used for correlation purpose followed the work of Seifert et al. (1979) and Palacas et al. (1986). Terpane parameters included the $\mathrm{C}_{19}-\mathrm{C}_{23}$ tricyclic terpanes, the $\mathrm{C}_{24}$ * tetracyclic terpane, $\mathrm{C}_{29}-\mathrm{C}_{30}$ pentacyclic terpanes, as well as gammacerane, a salinity indicator; from Sterane parameters included the $\mathrm{C}_{29} / \mathrm{C}_{27}$ sterane ratio, diasteranes, $\mathrm{C}_{30}$ steranes and pregnane. Aromatic steroids parameters included the compounds $\mathrm{C}_{27}, \mathrm{C}_{28}$ and $\mathrm{C}_{29}$, as for the corresponding steranes, but mainly used as maturity indicators (Peters and Moldowan 1993).

\section{Geological setting}

The Hellenide orogenic belt of Greece is divided into geotectonic zones, based on their paleogeographic position and the formation evolution. These zones are classified as "internal" (eastern) and "external" (western, Fig. 1), which have been affected only by the final Tertiary orogenic movements. Paleogeographically, the Gavrovo Zone was a shallow sub-sea ridge where carbonate platform rocks were deposited. This ridge separated the Pindos Trough (East) from the Ionian Trough (West). The Ionian Trough was a basin with semipelagic-pelagic sedimentation, 
and restricted Sub-basins, where favoured organic matter preservation (Karakitsios 1995). The Preapulian Zone was the slope of the Apulian Platform to the Ionian Trough.

Research on oil source rocks in the Ionian Zone has focused on the Vigla shales, the Posidonia beds and Triassic anoxic sediments. Five source rock horizons have been identified in this zone (Rigakis and Karakitsios 1998) and one main horizon in the Preapulian Zone (Rigakis 1999). The Early Miocene deformation of the External Hellenides caused a tectonic doubling of the Ionian Zone. The degree of maturation of the upper thrust sheet's sediments is generally low, while the sediments of the underlying thrust sheets are likely to be much more mature, or overmature (Rigakis 1999). The timing of oil generation is also favourable, because most oil was generated after orogenesis. Finally, the great number of Western Greece oil shows proves that oil generation has taken place in that area.

The main reservoirs in the Western Greece are the carbonate series of Eocene to Mesozoic age, while the best cap rocks are the Oligocene flysch and the Triassic evaporites. Porosity and permeability values are very low in the Eocene and Upper Cretaceous limestones; higher values are measured in the older horizons, for example the Pantokrator limestones, or the Triassic breccias (Karakitsios et al. 2001). Therefore, the Eocene limestones, which are the most likely to be found under cap rocks, are not such good reservoirs. Better conditions are expected in cases where due to tectonics under flysch Pantokrator or Vigla carbonates are found. The structures in the area are expected to be anticlines, fault blocks and paleo-reliefs (Roussos and Marnelis 1995). Sedimentary, stratigraphic or diapiric structures are expected less frequently.

\section{Oil shows in Western Greece}

The great historian of ancient Greece, HERODOTUS, in the fifth century B.C., had first mentioned the presence of an oil show in the Keri swamp of Zakynthos Island, where "oil wells out". Subsequently many others historians, geographers and other scientists have mentioned the presence of oil shows on Zakynthos and other areas of Western Greece.

Systematic analytical work of these oil shows started from 1980 by DEP, the state company responsible for oil exploration in Greece. Analytical results of some selected oil shows have been studied and published (Seifert et al. 1984, Palacas et al. 1986). In our work many more characteristic oil shows of the western Greece have been studied; furthermore this study is based in newer results of the geochemical research. The result is a more sophisticated classification of the western Greece oils.

Most of the Western Greece oil shows are located in the Ionian Zone, most of them in the eastern edge of the Botsara Syncline (Fig. 1). These oil shows are mainly impregnations to porous rocks, or to fractures, faults etc. However, there are oil seeps and dry bitumens as well. These oil shows are found in all the formations from Pliocene to Triassic. They are mainly found along faults, or on the contact of limestones with the overlying rocks. The oil migration took place along major faults, reverse faults, thrusts or diapiric faults (Nikolaou 2001).

Oil shows have also been found in most oil wells in the area. In the Lavdani-1 and Lavdani-2 wells oil shows were found along the thrust fault where flysch thrusted onto the Burdigalian sediments. In Lavdani-1, oil shows were also found in the flysch and the underlying limestone. In the Delvinaki-1 well, oil shows were found in the thrust fault zone of Triassic formations thrusted onto the flysch. In the wells Filiates-1, Aitoliko-1 and South Katakolo-1 oil shows were identified in Triassic formations. Dry bitumens were found in the Dragopsa-1 well inside the carbonate series and in Lippa-1 in clastic sediments of Radovisi Formation (Aquitanian). In the offshore Katakolo wells to the NW Peloponnesus, oil has also been identified; West Katakolo is actually a marginal oil field (Nikolaou 1986, Roussos and Marnelis 1995). As well as the oil shows, many indications of gaseous hydrocarbon seepage are found at outcrop and in wells of western Greece (Rigakis et. al. 2001). 


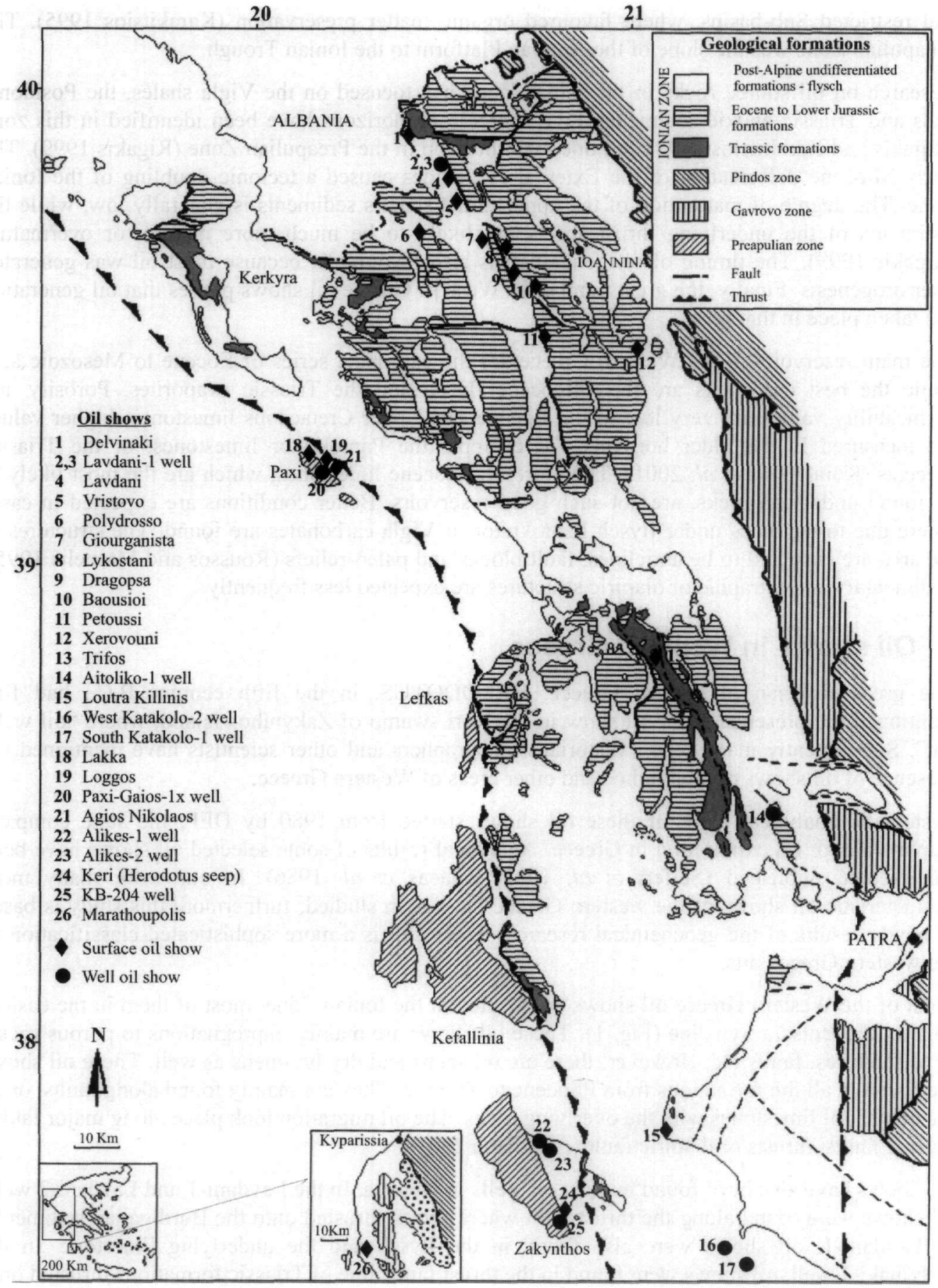

Figure 1 - Main geotectonic features and locations of characteristic oil shows in Western Greece

In the Preapulian Zone many oil shows are found in the surface and also in some wells. As well as the already mentioned Keri-Zakynthos oil show, other oils are known in the Paxi, Antipaxi, Lefkas and Zakynthos islands; it is also known one oil show in the sea between Zakynthos and Kefallinia islands. Their migration takes place along faults or unconformities (Nikolaou 2001). 
The most significant well with oil shows is the Paxi-Gaios-1x. Viscous oil identified, in MiddleUpper Jurassic carbonate rocks in the intervals $1500-1650 \mathrm{~m}$ and mainly at 1920-2120 m (Rigakis 1999). Dry bitumens are found in Cretaceous formations and in the Lower Jurassic and Triassic intervals. Analogous oil shows were identified in the corresponding formations of the Paxi-1 well. Remarkable oil shows were found in the wells drilled on Zakynthos Island. The viscous oil identified by the wells Alikes- 1 and Alikes- 2 occurs in limestones of Upper Cretaceous age. Oil shows also occur in the shallow wells drilled in the Keri swamp into marles and limestones of Eocene to Upper Miocene age; a small oil field without any economical value exists in that area.

The oil shows that were considered as more characteristic-representative have been analyzed by using standard geochemical methods. Results are described in Table 1.

Table 1 - Carbon isotope measurements and characteristic biomarker ratios of Ionian oils

\begin{tabular}{|c|c|c|c|c|c|c|c|c|c|c|c|c|c|}
\hline \multirow[b]{2}{*}{ No } & \multirow[b]{2}{*}{$\begin{array}{l}\text { Area/well- } \\
\text { Formation }\end{array}$} & \multicolumn{2}{|c|}{$\left(8^{13} \mathrm{C}\right)$} & \multirow[b]{2}{*}{ 点 } & \multicolumn{3}{|c|}{ Ster anes $(\mathrm{m} / \mathrm{z} 217)$} & \multirow{2}{*}{ 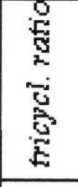 } & \multicolumn{4}{|c|}{ Terpanes (m/z 191) } & \multirow[b]{2}{*}{ है } \\
\hline & & 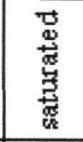 & 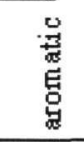 & & 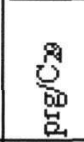 & $\underbrace{8}_{\substack{9 \\
0}}$ & 常 & & 罗 & לֶ. & d & $\underset{\mathrm{E}}{\stackrel{\mathrm{s}}{\mathrm{s}}}$ & \\
\hline & & & & & & & & & & & & & \\
\hline 1 & Delvinal & -29.4 & -29.4 & 0.64 & 0.96 & 1.62 & 0.89 & 0.16 & 1.63 & 1.56 & 1.07 & 0.30 & $C$ \\
\hline 2 & Lavd & 29.1 & -28.9 & 0.70 & 0.42 & 0.49 & 0.11 & 0.13 & 1.76 & 1.53 & 0.33 & 0.51 & $A 2$ \\
\hline 3 & Lavdarn & -28.1 & -28.3 & 0.58 & $\mathrm{ND}$ & $\mathrm{ND}$ & ND & ND & $\mathrm{ND}$ & $\mathrm{ND}$ & $\mathrm{ND}$ & $\mathrm{ND}$ & $A 2$ \\
\hline 4 & & -29.0 & -29.1 & 0.72 & 1 & 0.54 & 0.24 & 0.17 & 2.23 & 1.72 & 0.44 & 0.49 & $A 2$ \\
\hline 5 & & ND & -28.9 & 0.61 & 0.79 & 0.64 & 0.2 & 0.23 & 1.83 & 1.63 & 0.28 & 0.50 & $A 2$ \\
\hline 6 & P oly & -29.7 & -28.9 & 1.71 & 0 & 0.72 & 0 & 0.44 & 1.45 & 2.86 & 0.2 & $\mathrm{ND}$ & $B$ \\
\hline 7 & & -30.5 & -30.0 & 0.13 & 0.02 & 0.23 & 0 & 0.09 & 0.53 & 3.8 & 0 & ND & $A 2$ \\
\hline 8 & Lykos & -29.9 & -29.0 & $\mathrm{ND}$ & 0.55 & 0.52 & 0.12 & 0.47 & 1.80 & 1.89 & 0.15 & 0.23 & AI \\
\hline 9 & & -30.2 & -29.1 & ND & 1.00 & 0.71 & 0 & 0.62 & 1.86 & 2.00 & 0.23 & 0.21 & $A I$ \\
\hline 10 & $\mathrm{Bac}$ & -29.2 & -28.6 & $\mathrm{ND}$ & 0 & 0 & 0.48 & 0.24 & 2.30 & 6.95 & 0 & 0.40 & $A 2$ \\
\hline 11 & Petou & -29.1 & -28.8 & ND & 0.13 & 0.91 & 0.74 & 0.3 & 1.26 & 5.38 & 0.21 & 0.21 & $A I$ \\
\hline 12 & $\begin{array}{l}\text { Xerovou } \\
\text { Aitoloak }\end{array}$ & -28.8 & -29.4 & 0.50 & 0.42 & 0.74 & 0.15 & 0.08 & 0.40 & 0.96 & 0.31 & 0.16 & $A 2$ \\
\hline 13 & Trifos-? & -27.3 & -27.5 & 1.5 & 0.86 & 1.15 & 0.02 & 0.58 & 1.21 & 1.25 & 0.09 & 0.66 & $\boldsymbol{B}$ \\
\hline 14 & $\begin{array}{c}\text { Aitoliko-l, } 3962 \mathrm{~m} \text {-Triassic } \\
\text { NW Pelop onnesus }\end{array}$ & -25.6 & -27.1 & 0.57 & ND & $\mathrm{ND}$ & ND & ND & ND & $\mathrm{ND}$ & $\mathrm{ND}$ & $\mathrm{ND}$ & $C$ \\
\hline 15 & L. Killinis-Plioplei & -27.1 & -27.1 & ND & 3.64 & 0.74 & 0.21 & 0.52 & 2.03 & 2.06 & 0.15 & 0.19 & $B$ \\
\hline 16 & W.Kat. $-2,3533 \mathrm{~m}$-Vigla & -25.8 & -26.1 & 1.3 & 2.7 & 0.66 & 0.06 & 0.62 & 2.91 & 1.88 & 0.21 & 0.89 & $B$ \\
\hline 17 & S.Kat. $-2,2842 m$ - Triassic & -26.7 & -27.5 & 0.45 & 1.71 & 0.52 & 1.67 & 0.16 & 1.51 & 4.37 & 0.67 & 0.88 & $C$ \\
\hline
\end{tabular}

\section{Oil-oil correlation in Ionian Zone}

In the Ionian Zone, Epirus oils don't appear significantly different based on their carbon isotopes, so they can't be separated into different groups. However, carbon isotopes enable clear differentiation of the Epirus oils from the Peloponnesus and the Aitoloakarnania oils (Fig. 2), since the difference of their absolute values are greater than the limit of $3 \%$ (Sofer, 1984). Based on this, Epirus oils are classified as Group A. Oils of the Aitoloakarnania and Peloponnesus areas can be differentiated in two groups. Group B includes the oils of the West Katakolo-2 well, and the Loutra Killinis and Trifos oil seeps, while Group C includes the oils of the South Katakolo-1 and Aitoliko-1 wells. The genetic relationships of these groups are reinforced mainly from the results of the characteristic biomarker ratios, which are indicative of their origin. Furthermore from the biomarker study it is possible to further separation the Epirus oils into two subgroups. 


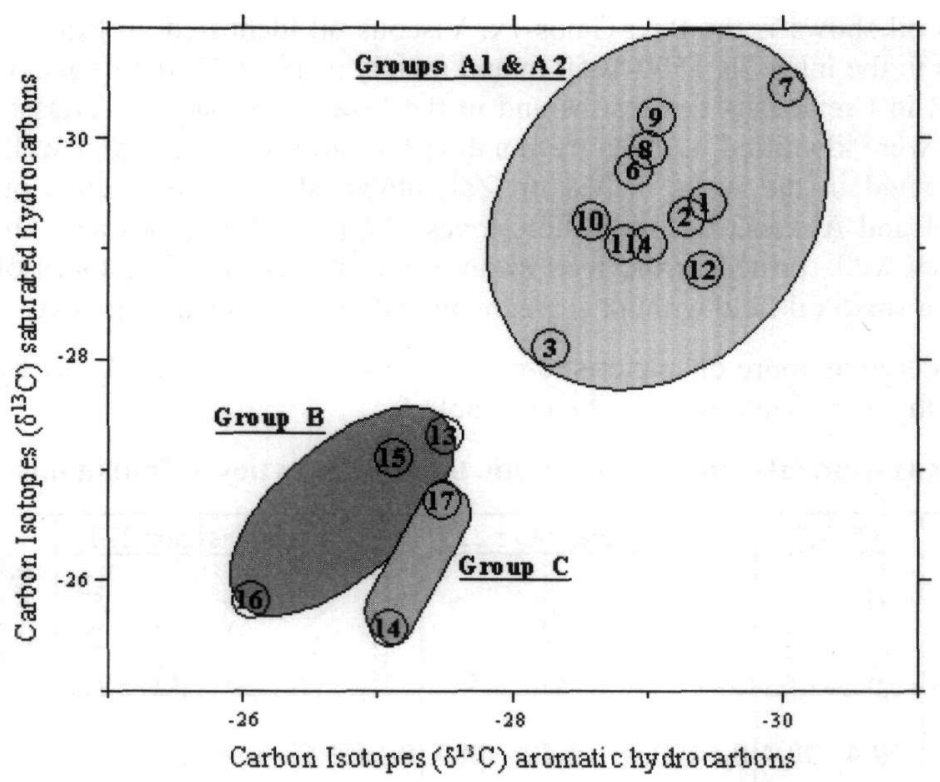

Figure 2 - Carbon isotopes of saturated vs. aromatic HC
The combination of the ratios pristane/phytane and $\mathrm{C}_{30} / \mathrm{C}_{29} \quad \alpha \alpha \alpha \quad 20 R$ steranes (Fig. 3a) first confirms the differentiation between the oils groups $\mathbf{A}$ and $\mathbf{B}$. In Group B is also classified the oil show from Polydrosso. The Loutra Killinis' oil as well as many Epirus oils is biodegraded, so pristane and phytane are altered and missing from oils, so they are not plotted in the diagram. In this diagram the differentiation of the Delvinaki and the $\mathrm{S}$. Katakolo oils (Group C) from all other oils is also well defined. The Delvinaki oil is found in tectonic contact between Triassic formations and the clastic sediments of Burdigalian age (Fig. 1). The geological setting leads the search for its source inside the Triassic sediments. Furthermore the S. Katakolo oil was found inside Triassic breccias. Results of laboratory analyses indicated that these oils have specific characteristics, which differentiate them from all other oils and justify their classification into the separate Group C. Differences are mainly focused on specific biomarker compounds including the high content of $\mathrm{C}_{30}$ sterane, a compound which characterizes marine depositional environments for the oil source rock (Moldowan et al. 1985). This compound is either absent or is present in very low quantity in the rest of the Western Greece oils.

The combination of the ratios pregnane/ $\mathrm{C}_{30} \alpha \alpha \alpha 20 R$ sterane and $\mathrm{C}_{30} / \mathrm{C}_{29} \alpha \alpha \alpha 20 R$ sterane (Fig. $3 b$ ) enables clear separation of the three already mentioned groups A (Epirus oils), B (W. Katakolo-Loutra Killinis) and $\mathbf{C}$ (Delvinaki-S. Katakolo). Trifos oil in this diagram is plotted inside the Epirus group; this could be a result of local depositional conditions of its source rock. Similarly the Baousioi and Petoussi oils appear different compared to the rest of the Epirus oils in this diagram, perhaps due to biodegradation.

Palacas et al. (1986) had differentiated the Epirus oils into two subgroups, based mainly on the difference of the compounds $\mathrm{C}_{19}, \mathrm{C}_{20}$ and $\mathrm{C}_{21}$ tricyclic terpanes. We tried to quantify this differentiation by using the ratio of $\mathrm{C}_{19}+\mathrm{C}_{20}$ tricyclic terpanes, characteristic of argillaceous source rocks, to the compounds $\mathrm{C}_{23}$ tricyclic terpane $+\mathrm{C}_{24}$ tetracyclic terpane, which are the predominant compounds in the early part of the $\mathrm{m} / \mathrm{z} 191$ mass chromatograms. We combined this ratio $(19+20) /\left(23+24^{*}\right)$ with a ratio of two pentacyclic terpanes, the gammacerane which indicates an evaporitic environment (Powell and Snowdon 1983, Moldowan et al. 1985) to the $C_{30} \alpha \beta$ hopane, which is one of the most dominant hopanes (Peters and Moldowan 1993). The combination of these ratios is plotted in the Fig. 3c; by this plot the separation of the Delvinaki and S. Katakolo oils from the rest of the Ionian Zone oils is obvious, which reinforces their classification into Group C. This separation is due to the high content of gammacerane in the oils of group $\mathbf{C}$, which differentiates them from all other oils. The rest of the Epirus oils are separated in two subgroups: The Subgroup A1 has a high content of $\mathrm{C}_{19}$ and $\mathrm{C}_{20}$ tricyclic terpanes and the Subgroup A2 has a low content of these compounds. These are characterized as subgroups because their differentiation is observed only in this diagram, due to their difference in the tricyclic terpanes. This difference is interpreted to be due to a facies difference in their common source rock. All the 
other characteristic biomarkers don't show any significant variation for the oils of these subgroups. Finally in this diagram the separation of the Subgroup A1 from the oils of Group B is not clear.

The oil show in the Aitoliko-1 well is absent from all these diagrams (Figs 3a-3c). For this oil, which was found in Triassic sediments, the only available analyses are the carbon isotopic determinations and the GC of the saturated HCs. Based on these data we constructed the diagram in Fig. 3d, which is a plot of the carbon isotopes of aromatic HCs to the pristane/phytane ratio. From this diagram it is concluded that the Aitoliko oil appears to have common characteristics with the S. Katakolo oil, and therefore we consider that Aitoliko oil also belongs to the Group C.
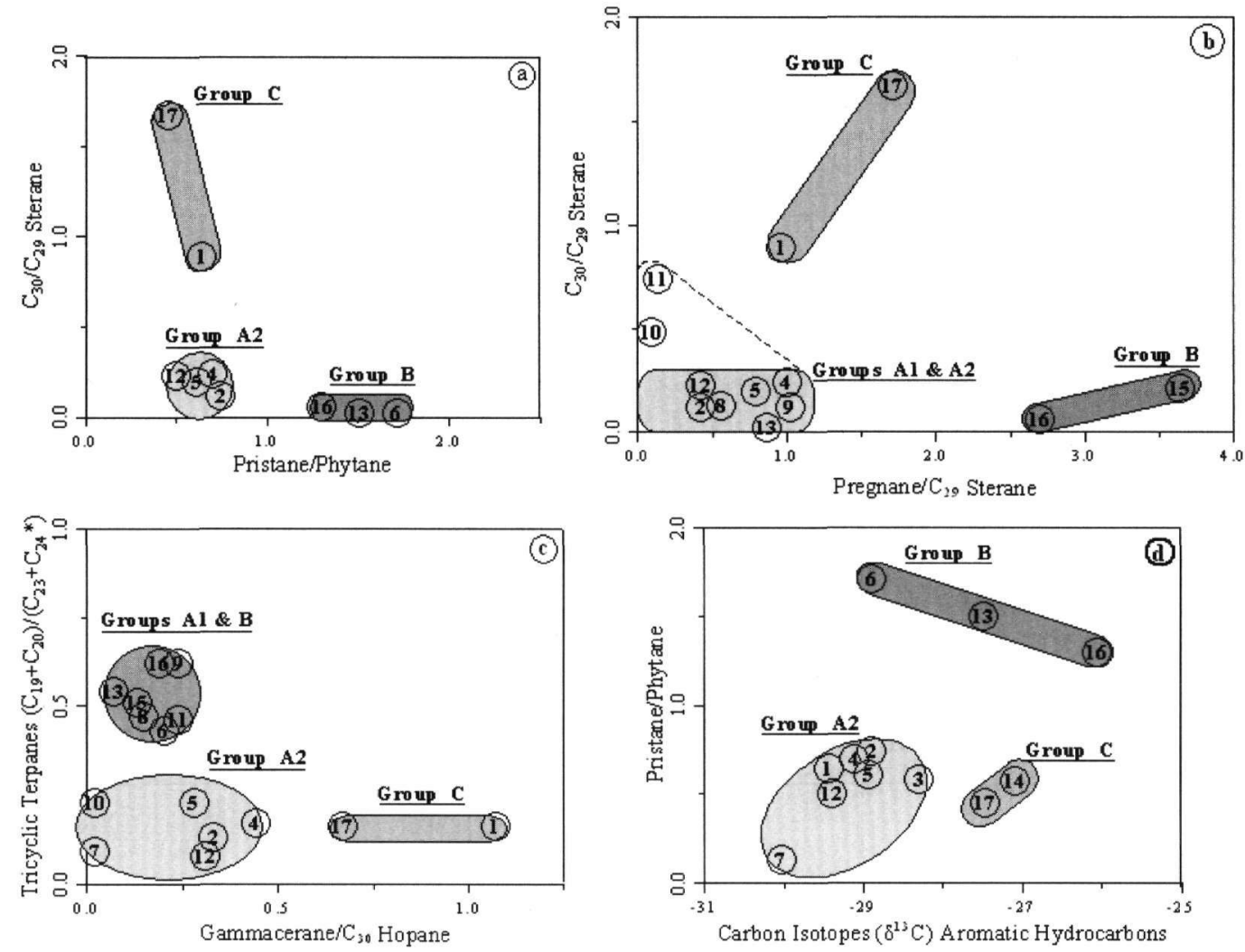

Figure 3 - Classification of Western Greece oil shows, based on characteristic biomarker ratios. For sample identification see Table 1

Based on the above correlations, there are three main groups of oils located in the Ionian zone: groups A, B and $\mathbf{C}$, with Group $\mathbf{A}$ divided into two subgroups, A1 and A2.

- In Subgroup A1 are the Dragopsa, Lycostani and Petoussi oils.

- Most of the Epirus oils are classified in Subgroup A2; the Lavdani-1 well oils, from $339 \mathrm{~m}$ (flysch) and $2435 \mathrm{~m}$ depth (limestone); the surface oil shows from Lavdani, Vristovo, Baousioi, Giourganista and the only oil analyzed from the internal Ionian Zone, the Xerovouni oil.

- In Group B are classified the Peloponnesus oils, the West Katakolo-2 oil, and the Loutra Killinis oil seep, as well as the Trifos oil seep from Aitoloakarnania. Characteristics of this group are also recognized in the Polydrosso (Epirus) oil.

- Group C consists of the Delvinaki oil show and the oils shows from the wells South Katakolo-1 and Aitoliko-1. 
In Figure 4 are shown characteristic chromatograms from oil shows representative of each group. As can be concluded from this figure and the analytical results (Table 1), many oils are highly biodegraded, so the low molecular weight compounds have been completely destroyed. In spite of this, many oils have significant amounts of hydrocarbons. However, the ratio of saturated to aromatics $\mathrm{HC}$ for all the Epirus oils is low, due to the significant content of aromatic $\mathrm{HC}$ in these oils. The low saturated/aromatic $\mathrm{HC}$ ratio can be the result of either immaturity or biodegradation but it is also apparent in non-biodegraded and relatively mature oils as well, such as the Lavdani-1 well oil at $2435 \mathrm{~m}$. Therefore, this ratio is at least sometimes a characteristic of oils of this area, and they are termed aromatic or aromatic-asphaltic oils. Exceptions to the above rule are the Trifos oil seep and the West Katakolo-2 oils, which have more saturated than aromatic HCs. This predominance of saturated $\mathrm{HC}$ could be a result of the relatively high maturity of these oils. These oils are characterized as paraffinic oils.

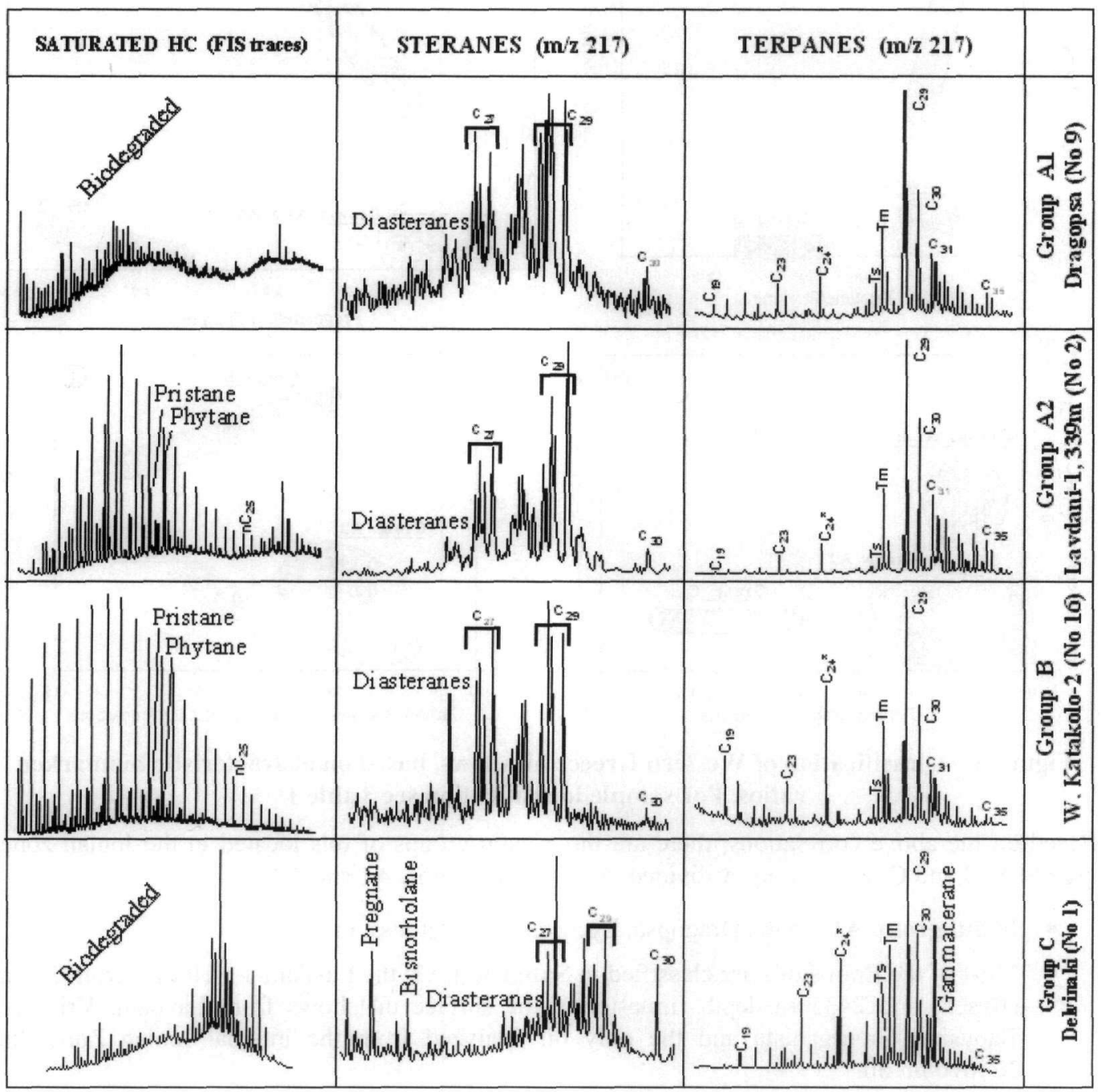

Figure 4-Characteristic chromatograms of oil shows representative of each group

\section{Ionian oils maturity}

Oil maturity provides more data that reinforce the above classification. Values of the $\mathrm{C}_{32}$ homohopane maturity indicator, the ratio $22 \mathrm{~S} /(22 \mathrm{R}+22 \mathrm{~S})$, in the oils of Group $\mathbf{A 1}$ are ranging 
between $0,56-0,59$. These values are a slightly lower than the equilibrium value of 0,60 (Peters and Moldowan 1993). Oils of Subgroup A2 have a slightly higher ratio, up to 0,62, so they have already reached the equilibrium value. Oils of Group B have reached the equilibrium value in $\mathrm{C}_{32}$ homohopanes, with one exception being the W.Katakolo-2 oil. The corresponding $\mathrm{C}_{31}$ homohopane ratio suggests immaturity for both the W.Katakolo-2 and Loutra Killinis oils. The equilibrium value has been established in all the oils of Group C.

From the maturity indicators of the $\mathrm{C}_{29} \alpha \alpha \alpha$ steranes it is concluded that most of the oils are mature; the ratio $20 \mathrm{~S} /(20 \mathrm{R}+20 \mathrm{~S})$ is either close to the limit, or slightly higher than the value of 0,40, which corresponds to the onset of oil generation (Peters and Moldowan 1993); only the oil show from Lavdani-1 well at $339 \mathrm{~m}$ and the Delvinaki oil show have low values for this ratio. On the contrary, the results of the $\mathrm{Ts} /(\mathrm{Tm}+\mathrm{Ts})$ ratio are indicative of immaturity for most of the oils, and only the Trifos oil seep has a high value, 0,48 , which corresponds to $0,6 \%$ vitrinite reflectance (Peters and Moldowan 1993).

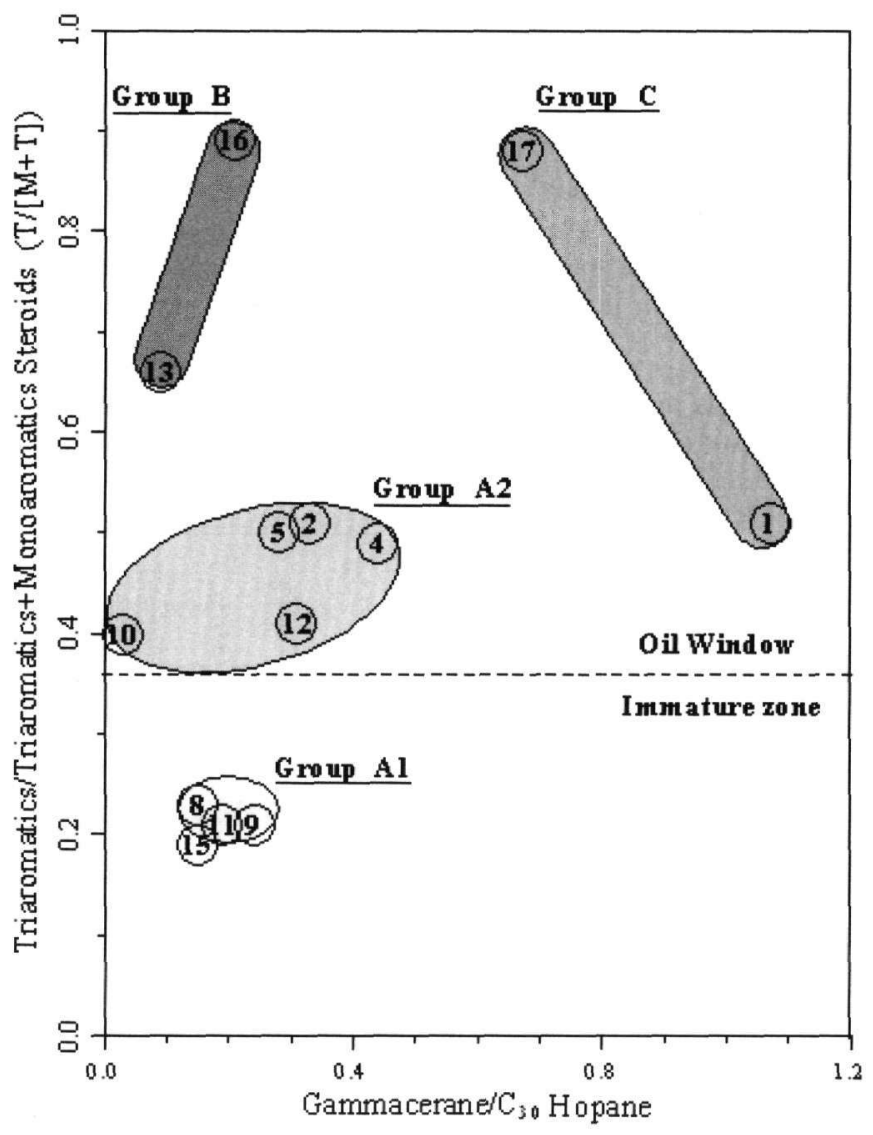

Figure 5 - Oil show classification based on their
maturity and depositional environment
The above results appear to show significant differences and are sometimes inconsistent. Furthermore in almost all of the samples equilibrium has been reached in the $\mathrm{C}_{32}$ homohopanes, which is a valuable maturity indicator for low maturities. Based on the above observations, we tried to find a more valuable ratio for predicting oil maturation. Therefore, we examined the ratio of triaromatics to monoaromatics plus triaromatics steroids (T/[M+T]) (Palacas et al. 1986, Peters and Moldowan 1993). This ratio gives low values for the oils of Subgroup A1, lower than the value of 0,36 which indicate the onset of oil generation (Peters and Moldowan 1993). Higher values have been measured for oils of Subgroup A2, while even higher values appear for Group B oils, with only one exception being the Loutra Killinis oil seep. High values also appear for the oils of Group C. These measurements have been plotted in the diagram of Fig. 5, against the gammacerane $/ \mathrm{C}_{30} \quad \alpha \beta$ hopane ratio, which is indicative of the depositional environment. This diagram reinforces the rightness of the oil grouping, making obvious the separation of the three main groups and the two subgroups of Group $\mathbf{A}$, with a unique exception being the Loutra Killinis oil seep, which is plotted close to Group A1 and not with Group B where it belongs based on other parameters. 
As a result of the above study, the oil maturity in Western Greece can be identified by using first the homohopane $\mathrm{C}_{32}$ ratio, and then the aromatic steroid ratio $\mathrm{T} /(\mathrm{M}+\mathrm{T})$. Based on these ratios the following results can be concluded.

Subgroup A1 oils have a low maturity and must have been generated before the main phase of oil generation. Slightly more mature are the oils of Subgroup A2, which were generated immediately after the onset of oil generation. Oils of Group B appear to be more thermally mature. However, for the West Katakolo-2 oil, the oil maturity may not be as high as is concluded from the aromatic steroids, since its homohopane ratio is relatively low. Its maturity degree is calculated to be about $0,7 \%$ vitrinite reflectance equivalent (Rigakis 1999). The most mature from all the oils is the $\mathrm{S}$. Katakolo-1 oil of Group C. In this oil there is equilibrium in the homohopanes and so the value of the ratio $\mathrm{T} /(\mathrm{M}+\mathrm{T})$ can be considered to be accurate, and representative of the real maturity, which is over the $1,0 \%$ vitrinite reflectance equivalent.

\section{Oil-oil correlations in the Preapulian Zone}

Geochemical analyses of oil shows were performed on well oils and on the surface oil shows too. One oil sample was analysed from the Paxi-Gaios-1x well, an oil splotch from the mud at $1986 \mathrm{~m}$. From Paxi Island three surface oil shows were also analysed, from the areas Agios Nikolaos, Loggos and Lakka (Table 2, Fig. 1). From Zakynthos Island oil shows were analysed from Keri, the Herodotus seep and one oil sample from the shallow well KB-206 at $30 \mathrm{~m}$ depth, and two more oils from the wells Alykes- 1 at $823 \mathrm{~m}$ and Alykes-2 at $963 \mathrm{~m}$. Together with the Preapulian oils it is also studied the Marathoupolis oil from Filiatra in the SW Peloponnesus, which is one of the very few oil shows known in the Gavrovo Zone.

Table 2 - Carbon isotope measurements and characteristic biomarker ratios of Preapulian and Gavrovo oils

\begin{tabular}{|c|c|c|c|c|c|c|c|c|c|c|c|c|c|}
\hline \multirow[b]{2}{*}{ No } & \multirow[b]{2}{*}{ Area/Well-Age } & \multicolumn{2}{|c|}{$\left(8^{13} \mathrm{C}\right)$} & \multirow[b]{2}{*}{ 愛 } & \multicolumn{3}{|c|}{ Ster anes $(\mathrm{m} / \mathrm{z} 217)$} & \multirow{2}{*}{ 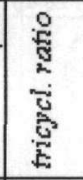 } & \multicolumn{4}{|c|}{$\underline{\text { Terpanes (miz 191) }}$} & \multirow[b]{2}{*}{ है } \\
\hline & & 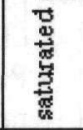 & 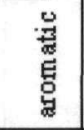 & & 要 & ర্d & $\underbrace{\infty}_{0}$ & & \begin{tabular}{l}
0 \\
\multirow{2}{*}{} \\
0 \\
0
\end{tabular} & ญ̊ำ & $\underset{0}{8}$ & $\underset{\mathrm{E}}{\stackrel{+}{\mathrm{E}}}$ & \\
\hline 18 & $\frac{\text { Paxi }}{\text { Lakka-Miocene }}$ & ND & ND & 1,8 & ND & ND & ND & ND & ND & ND & ND & ND & $\boldsymbol{E}$ \\
\hline 19 & Loggos-Eocene & ND & ND & 1,7 & ND & ND & ND & ND & ND & ND & ND & $\mathrm{ND}$ & $E$ \\
\hline 20 & Paxi-Gaios-1 $x$-M-A Juras. & $-25,6$ & $-26,3$ & 0,8 & 0,73 & 0,74 & 0,34 & 0,29 & 1,49 & 1,40 & 0,14 & 0,41 & $E$ \\
\hline 21 & Agios Nikolaos-Eocene & ND & ND & 1,9 & ND & 0,89 & 0,00 & 0,04 & 2,83 & 1,30 & 0,23 & 0,49 & $E$ \\
\hline 22 & $\frac{\text { Zakynthos }}{\text { Alyhes-I-Cretaceous-823m }}$ & -233 & -222 & 0.6 & 0.62 & 060 & 0.45 & 0.18 & 75 & & 0.15 & 0.41 & $D I$ \\
\hline 23 & Alyhes-2-Cretaceous- $963 \mathrm{~m}$ & $-22,1$ & $-21,9$ & ND & 1,25 & 0,79 & 0,90 & 0,19 & 2,14 & $\begin{array}{l}1,20 \\
1,06\end{array}$ & 0,18 & $0,41,56$ & $D I$ \\
\hline 24 & Keri (H erodotus)-Holocene & $-21,8$ & $-21,6$ & ND & 1,20 & 0,52 & 0,55 & 0,15 & 4,81 & 2,19 & 0,22 & 0,94 & $D I$ \\
\hline 25 & $K B-204,30 \mathrm{~m}$ - Tortorian & $-21,5$ & $-21,7$ & ND & 1,50 & 0,50 & 0,59 & 0,05 & 4,94 & 1,56 & 0,29 & $\mathrm{ND}$ & $D I$ \\
\hline 26 & $\begin{array}{l}\text { NW Pelop omiesus } \\
\text { Marathoupolis-Eocene }\end{array}$ & $-19,0$ & $-18,9$ & ND & 1,83 & 0,93 & 2,03 & 0,02 & 15,5 & 4,31 & 1,44 & ND & $D 2$ \\
\hline
\end{tabular}

Generally heavy values of carbon isotopes appear in all oil samples from Zakynthos Island (Fig. 6a), definitely differentiating these oils from the rest of Paxi Island oils, and also from the Western Greece oils. These oils constitute a different oil group, termed Group D. Even heavier isotopic values appear for the Marathoupolis oil; based on its isotopic values this oil can be classified to the Zakynthos Group, but differences in some of the characteristic biomarker ratios (Table 2, Fig. 6b) give reasons for its classification to a different subgroup. So, Group D is separated into two subgroups: Subgroup D1 containing the Zakynthos oils and Subgroup D2, the Marathoupolis oil. 
Concerning the Paxi oils, in all three surface oil shows preliminary geochemical analyses were performed, including solvent extraction, column chromatography and gas chromatography of saturated hydrocarbons (Table 2). Based on these analyses, all three oil shows can be characterised as identical. The Agios Nikolaos oil sample was also analysed by GC-MS for biomarkers. By comparing the biomarkers of this oil with the Paxi well oil (Fig. 6b) we conclude that all characteristic biomarker compounds from the surface and well oils are identical. Consequently all the Paxi oils are likely to have been produced by the same source rock.

Analytical data for the Paxi oils are different than the data of Zakynthos Group D1 oils (Figs 6a, b). Their isotopic analyses are similar to those for the corresponding analyses of Ionian zone oils Group B, while their biomarker ratios are similar either to the Group B oils, or to the Subgroup A1 oils (Table 1,2). The final conclusion is that the Paxi oils can not be classified to anyone of the Ionian oils group, but that they constitute their own group, the Group E.
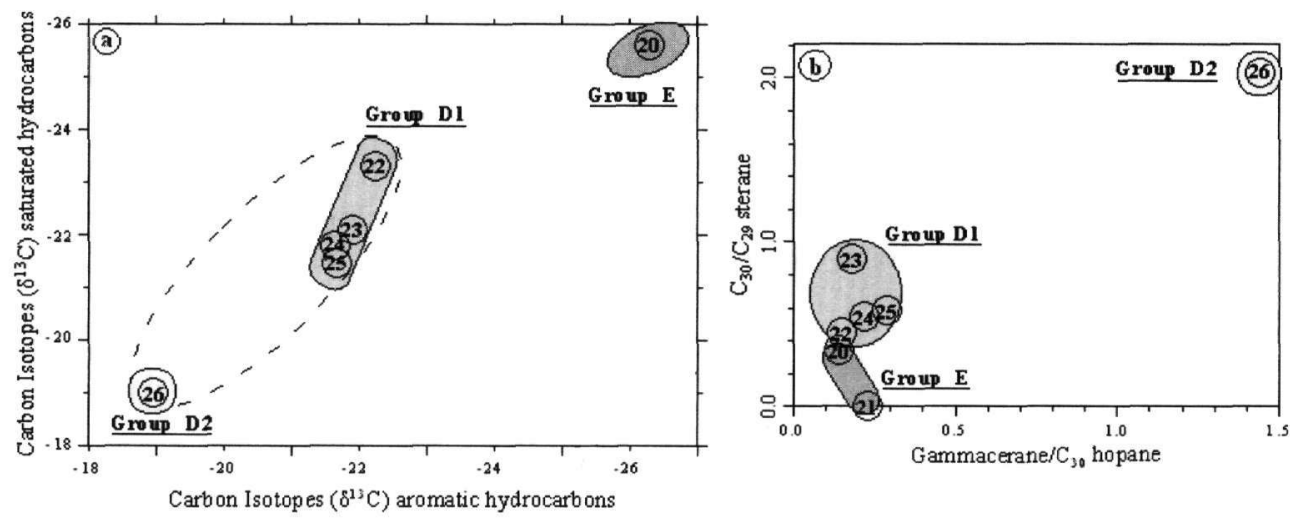

Figure 6 - Classification of Preapulian \& Gavrovo oils, based on carbon isotopes (a) and on characteristic biomarker ratios (b). For sample identification see Table 2

\section{Conclusions}

Analytical work on Western Greece oils indicated that because of the extreme biodegradation, the most useful methods for correlation studies are the carbon isotopes, and some characteristic biomarkers like the tricyclic terpanes, gammacerane, $\mathrm{C}_{30}$ sterane as well as the ratio $\mathrm{T} /(\mathrm{M}+\mathrm{T})$ in determining their maturity level. Based on these and on some more biomarker ratios, Western Greece oils are classified into five main groups, with two of them separated into two subgroups.

- Group A includes most of the Epirus oils. Subgroup A1 oils are derived from a shaly source and are less mature than the Subgroup A2 oils, which are derived from a carbonate source and were generated immediately after the onset of oil generation.

- Group B oils have a wide distribution from the Peloponnesus to Aitoloakarnania and to Epirus; they are quite thermally mature.

- Group C oils are found inside Triassic sediments of the Peloponnesus, Aitoloakarnania and Epirus. They are also quite thermally mature.

- Subgroup D1 includes the Zakynthos oils, while Subgroup D2 is the Marathoupolis oil.

- Group E includes the Paxi Island oils.

This differentiation indicates the presence of different source rock horizons, which have generated these oils. At least five different sources are anticipated to have produced these oils. The presence of so many different source rock horizons makes the further hydrocarbon exploration in Western Greece very promising. 


\section{References}

Claypool, G. E., Love, A. H., and Maughan, E. K., 1978. Organic geochemistry, incipient metamorphism, and oil generation in black shales members of Phosphoria formation, Western Interior United States, AAPG Bulletin, 62, 98-120.

Herodotus, 484-430 B. C. Histories, book D, verse 195.

Horvitz, L., 1985. Geochemical exploration for Petroleum, Science, 229(4716), 821-827.

Hunt, J. M., 1979. Petroleum geochemistry and geology, W. H. Freeman and Company (eds) $617 \mathrm{pp}$.

Karakitsios, V., 1995. The influence of preexisting structure and halokinesis on organic matter preservation and thrust system evolution in the Ionian basin, Northwestern Greece, $A A P G$ Bulletin, 79, 960-980.

Karakitsios, V., Rigakis, N., and Bakopoulos, I., 2001. Migration and trapping of the Ionian series hydrocarbons (Epirus, NW Greece), Bulletin of the Geological Society of Greece, XXXIV/3, 1237-1245, proc. of the 9th International Congress, Athens, September 2001.

Moldowan, J. M., Seifert, W. K., and Gallegos, E. J., 1985. Relationship between petroleum composition and depositional environment of petroleum source rocks, AAPG Bulletin, 69, $1255-1268$.

Nikolaou, K. A., 1986. Contribution to Neogen research and to geology and delimitation of Ionian and Preapulian zones in relation with petroleum geology observations in Strofades, Zakynthos and Kefallinia islands, Ph.D. Thesis, Athens University, 228pp.

Nikolaou, K. A., 2001. Origin and migration mechanism of the main hydrocarbon seeps in Western Greece, Bulletin of the Geological Society of Greece, XXXIV/3, 1213-1219, proc. of the 9th International Congress, Athens, September 2001.

Palacas, J. G., Love, A. H., and Gerrild, P. M., 1972. Hydrocarbons in estuarine sediments of Choctawhatchee bay, Florida, and their implications for genesis of petroleum, $A A P G$ Bulletin, 56, 1402-1418.

Palacas, J. G., Monopolis, D., Nicolaou, C. A., and Anders, D. E., 1986. Geochemical correlation of surface and subsurface oils, Western Greece. In D. Leythaeuser and J. Rullkotter (eds), Advances in organic geochemistry 1985, Org. Geochem., 10, 417-423pp., Pergamon Press Ltd.

Peters, K. E., and Moldowan, J. M., 1993. The biomarker guide. Interpreting molecular fossils in petroleum and ancient sediments. Prentice Hall (eds), 363pp.

Powell, T. G., and Snowdon, L. R., 1983. A composite hydrocarbon generation model, Erdol und Kohle-Erdgas, 36, 163-170.

Rigakis, N., 1999. Contribution to stratigraphic research on wells and outcrops of the Alpine formations in Western Greece, in relation to the petroleum generation efficiency of their organic matter, Ph.D. Thesis, Athens University, 255pp.

Rigakis, N., and Karakitsios, V., 1998. The source rock horizons of the Ionian basin (NW Greece), Marine and Petroleum geology, 15, 593-617.

Rigakis, N., Roussos, N., Kamberis, E., and Proedrou, P., 2001. Hydrocarbon gas accumulations in Greece and their origin. Bulletin of the Geological Society of Greece, XXXIV/3, 12651273. Proceedings of the $9^{\text {th }}$ International Congress, Athens, September 2001. 
Roussos, N., and Marnelis, F., 1995. Greece licensing round to focus on Western sedimentary basins, Oil and Gas Journal, 93(10), 58-62.

Tissot, B. P., and Welte, D. H., 1984. Petroleum formation and occurrence, Springer-Verlag, Berlin, 699pp.

Seifert, W. K., Moldowan, J. M., and Demaison, G. J., 1984. Source correlation of biodegraded oils. In P. A. Schenck J. W. De Leeuw and G.W.M. Lijmbach (eds), Advances in organic geochemistry 1983, Org. Geochem., 6, 633-643, Pergamon Press Ltd.

Sofer, Z., 1984. Stable carbon isotope compositions of crude oils: Application to source depositional environments and petroleum alteration, AAPG Bulletin, 68, 31-49. 